\title{
ТОТАЛІТАРИЗМ І ЛІТЕРАТУРА: ВІД ВЗАЕМОДІї ДО ВИКРИТТЯ
}

\author{
ОКСАНА ПУХОНСЬКА \\ Національний університет „Острозька академія”, Острог —Україна \\ oksana.pukhonska@oa.edu.ua; ORCID: 0000-0003-0543-4847 \\ TOTALITARYZM A LITERATURA: \\ OD INTERAKCJI DO ZDEMASKOWANIA

\section{OKSANA PUCHOŃSKA} \\ Uniwersytet Narodowy „Akademia Ostrogska”, Ostróg — Ukraina
}

\begin{abstract}
STRESZCZENIE. Zaistnienie totalitaryzmu w Europie po I wojnie światowej od lat jest obiektem zainteresowania badaczy różnych dziedzin nauki. Liczne prace opublikowane w ciągu ostatnich lat świadczą o interdyscyplinarnym charakterze posttotalitarnego dyskursu naukowego. Nader ważnym w tym kontekście wydaje się problem sztuki, a szczególnie - literatury, co stanowi przedmiot rozważań w proponowanym artykule. Autorka wskazuje na ówczesne wykorzystanie literatury jako instrumentu propagandy. Celem aktualnego badania jest również odbiór współczesnego tekstu literackiego jako próby artystycznego przemyślenia doświadczenia totalitaryzmu, postrzeganego jako trauma oddziałująca na funkcjonowanie współczesnych społeczeństw. Nieprzepracowana trauma przeszłości często powoduje nieprzewidywalny zwrot w polityce europejskiej.
\end{abstract}

Słowa kluczowe: totalitaryzm, literatura, doświadczenie traumatyczne, ideologia, pamięć.

\section{TOTALITARIANISM AND LITERATURE: FROM INTERACTION TO DETECTION}

\section{OKSANA PUKHONSKA}

The National University of Ostroh Academy, Ostroh — Ukraine 
ABSTRACT. Researchers from different branches of science are interested in the reasons and conditions of the emergence of totalitarianism in Europe following the First World War. Numerous contemporary studies provide evidence about different ways of explaining post-totalitarian discourse. What is very important in such studies is the problem of art, especially that of literature. The article is devoted to revealing the connections between that regime and the art of word. The author analyzes the peculiarities of using literature as an instrument of propaganda. In addition, one of the main problems of current research is the contemporary ways of artistic rethinking and the process of working out the totalitarian experience. Primarily, it is represented as a trauma that influences the behavior of modern societies and very often provokes unpredictable turns in European policy.

Keywords: totalitarianism, literature, traumatic experience, ideology, memory.

$\Pi$ роблема виникнення тоталітаризму є вкрай важливою для з’ясування наслідків його впливу на сучасні посттоталітарні культури. Особливо, якщо ці культури досі відчувають вплив травматичного досвіду, пережитого внаслідок режимних дій, спрямованих на знищення національних ідентичностей, деформацію пам'яті минулого, заборону будь-яких індивідуальних самовизначень тощо. До таких культур належить передовсім українська. Численні суспільні протести, революції, війна на Донбасі — це не так наслідки геополітичних конфліктів, як перманентні намагання повернутися до власне української тожсамості, увиразнити національні травми, ідентифікувати культурні та людські втрати, чого не відбулося відразу ж після розпаду СРСР. Проблема тоталітаризму є також ключовою у визначенні специфіки iї сучасної літературної інтерпретації, адже більшість художніх творів, котрі різною мірою апелюють до реконструкції минулого, чи не вперше виразно вербалізують ті актуальні теми, які досі є незручними та провокують непорозуміння поміж самими українцями.

Появу тоталітаризму в повоєнній Європі дослідники зводять до щонайменше кількох причин. Найбільш оптимальною видається та, що пов'язана iз розпадом імперських моделей старого світу. Як наслідок, європейські суспільства, ще фактично перебуваючи в стані стагнації, спровокованої подіями Першої світової війни, не були здатними до критичної оцінки ситуації, що визрівала в окремих політичних середовищах. Свідомість значної частини європейського населення, котре врешті вивільнилося 3-під імперіальної залежності, була не настільки зрілою, аби зрозуміти небезпеку пропонованого нового устрою світу. Як вважає Міловіт Кунінський, виникнення нових держав на руїнах вчорашніх імперій спричинило те, що на європейській авансцені нового часу отримали слово як “народи з історією”, так і “народи без неї” [Kuniński 2006: 134], а тому відсутність у більшості постімперських націй державотворчої традиції призвела до дезорієнтації окремих народів із домінуючою досі залежною свідомістю. Через те вчасно запропоновані і близькі масам ідеї націоналізації та соціальної рівності виявилися цілком успішними. 
Для постімперських народів Європи тоталітаризм стає реакцією на колоніальну історію. Для його апологетів — це найкраща можливість виходу на географічну та історичну арену світу представників соціальних низів.

Ханна Арендт, дошукуючись “джерел тоталітаризму”, доходить висновку, що XX століття стає століттям мас, які відіграли ключову роль в становленні нового порядку. Хосе Ортега-і-Гассет, утім, зауважує, що поняття мас не є винаходом XX століття. Вони існували раніше, одначе перебували на задньому плані соціальної сцени; тепер же вийшли на авансцену [Ортега-и-Гассет 1997]. Приналежність до маси, за концепцією філософа, стає загальною соціальною ознакою людини без індивідуальності, безликої, такої, що нічим не відрізняється від інших.

Так зване умасовлення, на думку Романа Бекера, стає найголовнішою метою правдивого комуніста чи фашиста. Досягнута таким чином єдність дає необхідне для кожного почуття визнання власного існування іншими; у цьому випадку — організацією [Bäker 1992: 61]. з одного боку, така людина не мислиться як індивід, лише як частина неокресленого цілого, людина уколективнена, з домінуючим стадним інстинктом; з іншого ж - відчуває повну відірваність від притаманної людській сутності потреби приналежності до певної групи, колективу, соціуму, які теж умасовлені і позбавлені права iншої, відмінної від пропагованої режимом, візії навколишніх реалій.

Еріх Фромм специфіку виникнення тоталітарного режиму загалом кваліфікує як “утечу від свободи”. У центрі такого постулату він ставить передусім психологію людини, що переживає усі кризи нового століття, та філософію творення іншої суспільної свідомості на руїнах поваленого війною, революціями, часом світу. Філософ зауважує, що, „окрім проблеми економічних i соціальних умов, котрі сприяли виникненню фашизму, існує і проблема людини як такої, котру також треба зрозуміти" [Фромм 1998: 18]. Наслідки Першої світової війни позбавили людину не лише звичного способу життя, а й передусім певності безпеки. Психологічна нестабільність, страх і скрута кидали iї із крайності в крайність у пошуках грунту під ногами та гіпотетичного захисту від невідомості. Пропозиція колективних формувань давала ілюзорні сподівання на вихід зі стану стагнації, а також знімала індивідуальну відповідальність індивіда перед державою. Натомість вимагались абсолютне самозречення та відмова від приватності. Така поведінка цілком виправдовує психологію натовпу, за якою, як переконує Густав Лебон, свідому діяльність індивіда заміщує несвідома діяльність маси [Лебон 1995].

Осмислюючи та аналізуючи особливості тоталітаризму та його впливу на суспільну свідомість, а також ідентичність наступних поколінь, текст сучасної художньої літератури постає метафоричним медіумом поміж пам'яттю історичною та теперішньою. Літературний твір, описуючи травматичний досвід посттоталітарного суспільства, сьогодні найповніше розкриває проблеми, які 
мають вирішальний вплив на геокультурну політику посттоталітарної держави. Теоретик мистецтва Ігор Голомшток зазначає, що саме у XX сторіччі пряма залежність форм мистецтва, його стилістики і мови від нав'язуваної зовні ідеології стала естетичною закономірністю із настільки трагічним значенням, якого не було в жодній із попередніх епох [Gołomsztok1980: 6].

Українська література сьогодні демонструє подвійну поставу супроти тоталітарного минулого. По-перше, прочитуємо в ній стійкий протест проти соцреалістичної спадщини, втілений у тривалих пошуках властивих форм мистецького самовираження (здебільшого таке явище спостерігаємо ще на початку 1990-х у творах Ю. Андруховича, О. Ульяненка, В. Кожелянка, А. Санченка). По-друге, сучасне українське письменство вдається до тотальної ревізії наслідків культурної стагнації, спровокованої досвідом багатолітнього тоталітарного терору (С. Жадан, О. Забужко, Ю. Винничук).

Тоталітаризм, як відомо, посягнув передусім на свободу особистості, думки, слова, які були вкрай необхідними для природного розвитку літератури. За Джорджем Орвеллом, який свого часу пройшов шлях від захоплення до повного розчарування тоталітаризмом, у рамцях таких режимів заборонялося не тільки висловлюватись, але й думати. Що більше, вказували, що потрібно думати; втілювалась ідеологія, яка мала бути акцептована більшістю, а відтак нав'язувалася модель поведінки, контролю підлягали навіть емоції [Оруэл 1989: 244]. У таких умовах художня словесність, яка мала би відображати вільні погляди автора на актуальні реалії, опиняється під тотальною загрозою. Ще у 1941 році Дж. Орвелл передбачив: якщо тоталітаризм стане явищем всесвітнім і перманентним, література, якою ми ії знаємо, просто перестане існувати [Оруэл 1989: 245]. Як результат, саме в радянському варіанті література стала рупором режимної ідеології, втіленої в концепції соцреалізму, а письменникам була відведена роль “інженерів людських душ”.

Ідеологічна історія мистецтва, за І. Голомштоком, завжди починається із проголошення його знаряддям створення нової - пролетарської, арійської, фашистської чи комуністичної — культури i, як наслідок цього, із заперечення всіх попередніх та існуючих культурних форм [Gołomsztok 1980: 7]. Література в такому контексті посідала місце чи не найважливішого транслятора ідеологічних смислів і служила ефективним механізмом перетворення суспільної свідомості на свідомість масову. Владний підхід до ролі літератури в утвердженні режимної ідеології був чітко продуманий. У нацистській Нiмеччині 22 вересня 1933 року була створена Імперська палата культури, до

\footnotetext{
${ }^{1}$ Єжи Гедройць - польський публіцист і громадський діяч в еміграції. Засновник і головний редактор часопису „Kultura”. 3 його ініціативи та його коштом з'явилася друком антологія української літератури 1917-1933 років Розстріляне відродження, впорядкована Юрієм Лавріненком. „Розстріляне відродження” як пропозиція назви книжки вперше прозвучала у листі Гедройця до Лавріненка від 13 серпня 1958 року.
} 
якої входила Імперська палата літератури. Цей підрозділ чітко відстежував і цензурував літературні тексти, які мали перспективу бути опублікованими і потрапити до читача. Роком раніше, а саме 23 квітня 1932 року в Радянському Союзі була створена Спілка письменників СРСР, завданням якої була чітка регламентація і контроль письменницької діяльності. Ця Спілка мала визначені цілі і завдання: поширювати та утверджувати ідеї партії, прославляти досягнення радянського суспільства, власне, виховувати радянське суспільство. Окрім того, в СРСР були створені численні органи цензури, підзвітні так званим органам безпеки, які визначали долю кожного письменника і кожного літературного тексту.

Ті художні твори, котрі претендували на мистецьку оригінальність та відображали сутність, що суперечила впроваджуваній ідеології, опинилися під забороною, знищувалися, їхні ж автори були репресовані. Наслідком цього в українській культурі маємо ціле покоління митців, які Єжи Гєдройць ${ }^{2}$ запропонував найменувати цілком вдалою метафорою - розстріляне відродження (Валер'ян Підмогильний, Валер'ян Поліщук, Микола Куліш, Микола Хвильовий, Михайль Семенко, Свген Плужник, Микола Зеров, Лесь Курбас та ін.).

3 приходом до влади нацистів у Німеччині спостерігається масове спалення книг ${ }^{3}$, закриття бібліотек, вилучення з навчальних та наукових установ літератури, яка суперечила ідеологічній доктрині нової влади. Комуністичний режим у Радянському Союзі проводив репресії інтелігенції, вилучав із публічного обігу літературу національно-історичного змісту і ту, котра відображала новітні мистецькі віяння. Модерністичне мистецтво для мистеитва піддавалося тотальній ревізії, здійснювалась його повна політизація. У цьому контексті X. Арендт звертає увагу на суттєву відмінність у підпорядкуванні культури поміж нацистським та комуністичним тоталітарними режимами. На iï думку, нацисти все ж не вбивали своїх талантів [Арендт 1996: 450]. Утім, значення свойх у націонал-соціалістів, як відомо, грунтувалось переважно на теорії раси, тоді як у більшовиків — на прихильності та пропаганді партійної ідеології.

За спостереженнями Бориса Будена, комуністичні політики не були ні літературознавцями, ні істориками мистецтва, однак беззастережно бралися за створення безальтернативного і єдино правильного "твору мистецтва" -

${ }^{2}$ Єжи Гедройць - польський публіцист і громадський діяч в еміграції. Засновник і головний редактор часопису „Kultura”. Зйого ініціативи та його коштом з'явилася друком антологія української літератури 1917-1933 років Розстріляне відродження, впорядкована Юрієм Лавріненком. „Розстріляне відродження” — такапропозиція назви книжки вперше прозвучала у листі Гедройця до Лавріненка від 13 серпня 1958 року.

${ }^{3} 10$ травня 1933 за ініціативою міністра народної просвіти і пропаганди Геббельса нацистами була влаштована жахлива акція спалення книг. На територіях майже всіх німецьких університетів у багаття потрапляли твори знаменитих німецьких та зарубіжних письменників і мислителів (Г. Манна, Е. Глезера, Е. М. Ремарка, 3. Фройда та ін). 
соціалізму. Разом із тим вони були його критиками і експертами в справі поетики і жанру — деміургічної поетики будови нового світу [Buden 2012: 148]. Нова ж література була покликана впроваджувати в культурний дискурс виключно тоталітарні ідеї, позбавляючи суспільство естетичної альтернативи. Саме тому на авансцену радянської літератури виходять безкомпромісні адепти режиму і адоранти культів вождя й партії: фадєєви, островські, тіхонови й ін. Це той випадок, який Дж. Орвел визначає як повну ізоляцію від зовнішнього світу, метод ув'язнення особистості у штучному середовищі через позбавлення іiі можливостей порівнювати.

Терор супроти культурної еліти (інтелігенції, духовенства, митців, освітян), етнічних меншин (та й, зрештою, цілих націй), неповносправних індивідів не лише був поширеним методом так званих тоталітарних чисток. 3 погляду ідеологічної пропаганди він був методом виправданим, оскільки тільки так можна викорінити “неблагонадійні”, “ворожі” елементи. Один із найжорстокіших винаходів тоталітаризму, що служив для розправи із такими “неблагонадійними”, - концентраційні табори. Було це не лише місце позбавлення волі, примусової праці чи фізичного знесилення, а й середовище духовного і морального нищення. Українська література сьогодні, за винятком окремих художніх творів (Янгол у сірому Н. Гуменюк, Лииарі любові і надіі Л. Романчук, Червоний А. Кокотюхи), мемуарів, які порівняно недавно стали доступними широкій громадськості, та індивідуальних досліджень (скажімо, монографії Надії Колошук Табірна проза в парадигмі постмодерну (2006)), практично не порушує табірної теми, на відміну від літератури європейської, котра активно пропрацьовує травму гітлерівських концтаборів упродовж кількох десятиліть.

Сучасна літературна молодь відчуває не страх перед травмою, а надмір непроговореної травматичної пам'яті. Оминути ії не вдасться через різні обставини. А тому поруч із документально-художнім Іншим світом (A World Apart: a Memoir of the Gulag, 1951) Густава-Герлінга Грудзінського з'являються вже художні Iсnанські очі (Hiszpyńskie oczy, 1993) Марії Нуровської, а через тривалий час і Mamepi (Matky, 2011) Павола Ранкова, із Димами над Біркенау (Dymy nad Birkenau, 1945) Северини Шмаглевської, з'являється Хлопчик в карmaтій піжамі (The Boy in the Striped Pyjamas, 2006) Джона Бойна чи Крадійка книжск (The Book Thief, 2005) Маркуса Зузака та ін. Однак саме сталінські табори в сучасній українській літературі досі залишаються в тіні ширшого контексту проблеми, а саме — тотальної репресивної політики СРСР супроти української національної свідомості. Причини цього цілком очевидні. Пострадянська пам'ять a priori асоціює комуністичне минуле з суцільним концентраційним табором, в якому “залізною рукою заганяли людину до щастя”. Як наслідок, травматична пам'ять ГУЛАГу досі залишається однією з найменш проговорених в українській пострадянській літературі. Не можемо оминути 
увагою той пласт художніх і документальних текстів, який був удоступнений українському читачеві після падіння залізної завіси. Сьогодні маємо доступ до низки текстів, опублікованих свого часу в еміграції: Жорстокі світанки (1947), Доба страхіть (1953) Степана Любомирського, відомі твори Уласа Самчука та Івана Багряного, На роздоріжжях смерти (1949) М. Приходька, 595 днів совстським в'язнем (1950) І. Німчука, Ухта-Печорський концтабір (1952) М. Шкварка, Заметений шлях. Спогади про хресну дорогу розкуркулених (1974) К. Каздоби, Bratz: німецький конщентраційний табір (спогади в'язня) (1946) В. Мартинця, Ravensbruck - найбільший жіночий концентраиійний табір в Німеччині (1947) Олени Вітик-Войтович та ін. Лектура цих текстів відкриває нові перспективи рецепції нащадками українського досвіду як сталінських, так і гітлерівських таборів.

Ще однією особливістю тоталітаризму, що визначає його стратегічні цілі i завдання, $є$ безпрецедентне посягання на сакральну культуру підкорених народів, а саме - на духовність, яка в українській культурі грунтувалася на християнській релігії та церкві. У процесі утвердження тоталітарної доктрини відбувається ефект заміщення однієї релігії іншою. Своєю ідеологію, за Барбарою Ольшевською-Дионізяк, творці тоталітарних режимів прагнули замінити релігію інших визнань [Olszewska-Dyoniziak 1999: 19], таким чином позбавивши себе перспективи конкуренції у плані сакралізації вождя як безпрецедентного і єдиного. Саме комунізм і нацизм стають новими релігіями, релігіями сучасними. За К. Хейсом, втрата масами довіри до сакрального Бога, Бога трансцендентного компенсується його заміщенням “діонісійським племінним богом" крові і землі та “лукреційським богом” фаталізму і матеріалізму [Науеs 1940: 100].

Переосмислення цінностей, у тому числі й духовних, призводить до здомінування серед мас матеріалістичної “релігії”, пропонованої новим режимом диктаторів. Атеїстична позиція комуністичного режиму, як і будь-якого авторитарного режиму, виключала можливість існування інших авторитетів, окрім вождя і партії. А тому позбавлення людини права віри у трансцендентне — це запорука її швидкого надлому, а також того, що вона “не знатиме інших богів”, крім тих же вождя і партії. Специфіка атеїстичної концепції передбачала також, що тоталітарний режим культивував тримання свідомості особистості і соціуму в перманентному страхові, тоді як релігія декларувала спасіння, можливість спокутування гріха, любов. Е. Фромм зауважує, що церква, хоча і „нав’язувала індивідові відчуття провини, проте запевняла його у своїй безумовній любові й давала можливість усім своїм дітям вірити у те, що Господь їх любить і пробачить" [Фромм 1998: 63]. А тому до Бога почувалось більше довіри і любові, аніж сумніву і страху. Християнська релігія безальтернативно була однією із основ традиційної культури українців. Церква в період тоталітаризації лишалась останнім форпостом надії і сподівання на більш гуманний хід історії. 
Втрата цього форпосту неминуче вела за собою апатію і підривала останній стимул до опору. Образ батюшки Ігната із Розколотого неба Світлани Талан, коли його із храму „вивели у рясі з хрестом на грудях, не дали навіть вдягнутися. Руки його були заведені назад та зв' язані мотузкою" [Талан 2014: 123] — це метафора української церкви в перші десятиліття активної радянізації.

Такі обставини цілком змінили світоглядні орієнтири суспільства. Однак і філософічні тенденції початку століття, як відомо, змінилися таким чином, що проблема релігії була піддана радикальній ревізії. Бог, який, за Ф. Ніцше, втратив своє сакральне значення, більше не вселяв безсумнівної довіри і не сповняв надії мас на майбутнє. Це також послужило стимулом до формування абсолютно нових світоглядних парадигм. Тоталітаризм упровадив інший ідеал і культ лідера. Цим уповні скористалися творці нового світового порядку. Ліквідація релігійного чинника на ранніх етапах становлення радянської держави згодом сприяла активному вихованню так званого типу homo sovieticus, якого Р. Бекер, вслід за Теодором Адорно, наділяє характеристичним рядом ознак: авторитарною підкореністю, браком критицизму супроти ідеалізованих авторитетів, а в разі тимчасової відсутності цих авторитетів - агресивним їх відшукуванням, тенденцією до виключення зі своєї групи осіб, що порушують конвенціональні цінності стереотипним мисленням, деструкцією і цинізмом [Bäker 1992: 66]. Т. Адорно у цих ознаках вбачає одну з фундаментальних засад режиму, а саме: наявність вождя, творення і підтримування його культу, що забезпечує авторитарний характер тоталітаризму, а також існування ядра, навколо якого вибудовується система, ідея, ідеологія.

Оскільки опорним елементом тоталітарної системи ставала маса, то характерно, що наявність авторитету, своєрідного “вожака стада", на якого підсвідомо покладалась вся відповідальність, була обов'язковою. Така особливість характерна практично всім режимам: фашизму в Італії, нацизму в Німеччині, комунізму в СРСР тощо. Вождь, окрім обов'язку лідера і провідника, мав також замінити Бога, який, як проголосив Ніцше, помер. Густав Лебон, пояснюючи психологію маси, зауважує, що натовп людей, подібно до стада тварин, інстинктивно підкоряється владі вождя, тому що він $є$ тим ядром, навколо якого кристалізуються і об'єднуються погляди [Лебон 1995]. Здобувши безсумнівний авторитет, вождь через свої засоби управління ці погляди насаджує. Правитель в тоталітарній ідеї ставав особою провіденційною, гарантом людської безпеки і спокійного життя. Чим більш катастрофічною виглядала суспільна ситуація, а традиційні до того часу цінності, норми і структури втрачали свою актуальність, тим інтенсивнішою ставала потреба вождя [Bäker 1992: 32]. На нього покладалась відповідальність за все, що відбувається. Тому рішення вождя та методи їхнього втілення в життя не викликали жодних сумнівів і застережень.

Переоцінка цього аспекту тоталітаризму здійснюється в численних сучасних літературних творах. Прикметні в цьому плані тексти - це згадані вище 
Червоний та Чорний ліс А. Кокотюхи, Лицарі любові та надї Л. Романчук, Розколоте небо С. Талан. Що більше, саме ці твори трактують проблему значно ширше. Десакралізуючи образи великого переможия, батька народів, ефективного менеджера в особі Сталіна, сучасні письменники звертаються до історичних реалій, знаходячи все більше спільних ознак у політиці Гітлера і Сталіна, особливо в їхньому ставленні до захоплених народів. Розвінчуючи ідеологічні радянські міфи про хорошого і поганого правителів, чимало сучасних дослідників доходять висновку, що не має і не може бути позитивного виміру тоталітаризму. Норман Наймарк, наприклад, у праці Геноциди Сталіна зауважує, що „обидві системи, сталінська і нацистська, були геноцидними за самою своєю природою. В обох випадках специфічне поєднання харизматичних лідерів (у Веберовому розумінні), диктаторських повноважень, ідеологічної мотивації та прометеївських трансформаційних поривань призвело до того, що вони використовували масове знищення груп громадян власних (i чужих) країн, щоб досягнути неможливого майбутнього, яке визначало саму їхню сутність” [Наймарк 2011: 107].

У висновку випадає зазначити, що політика тоталітаризму (причому в різних його варіантах) базувалася на дискредитації минулого і створенні такого суспільства, яке про минуле мало право знати лише те, що б не суперечило офіційній доктрині ідеології. Тоталітарний режим бере на озброєння маніпулювання історичною та культурною пам'яттю, а художня література виявилася дієвим інструментом у реалізації такої практики. В умовах посттоталітарної дійсності важливо всіляко розвінчувати цю порочну традицію. Сучасні тексти покликані не лише виправити ситуацію, а й відкрити ті модифіковані пропагандою сторінки минулого, які дають можливість травмованим тоталітаризмом суспільствам повернути собі власну ідентичність.

\section{Список використаної літератури}

Buden B., Strefa przejścia. O końcu postkomunizmu, tłum. M. Sułowski, Warszawa: Wyd-wo Krytyki Politycznej, 2012.

Bäker R., Totalitaryzm. Geneza. Istota. Upadek, Toruń: INDEX BOOKS, 1992.

Gołomsztok I., Język artystyczny w warunkach totalitarnych, thum. A. Mazur, London: Polonia

Book Fund L.t.d, 1980.

Hayes C.J., The Novelty of Totalitarianism in the History of Western Civilisation, [in:] „Proceedings of the American Philosophical Society”, 1940, 82(1), p. 91-102.

Kuniński M., Totalitaryzm w ujęciu Hanny Arendt, [w:] „Totalitaryzm a zachodnia tradycja”, Kraków, 2006, s. 116-142.

Olszewska-Dyoniziak B., Antropologia totalitaryzmu europejskiego XX wieku, Wrocław, 1999. Арендт Х., Истоки тоталитаризма, перев. И. В. Борисова, Ю. А. Кимелева и др., Москва: ЦентрКом, 1996. 
Лебон Г., Психология народов и масс, Москва: Макет, 1995,[в:] Електронний ресурс: http:// royallib.com/book/lebon_gustav/psihologiya_narodov_i_mass.html (14.03.2020).

Наймарк Н., Геночиди Сталіна, перекл. В. Старк, Київ: Видавничий дім „Києво-могилянська академія", 2011.

Ортега-и-Гассет Х., Восстание масс, перев. А. М. Гелескул, [в:] Електронний ресурс: http://lib.ru/FILOSOF/ORTEGA/ortega15.txt_with-big-pictures.html (14.03.2020).

Оруэл Дж., “1984” и эссе разных лет, перев. В. С. Муравьев, Москва: Прогресс, 1989.

Талан С., Розколоте небо, Харків: Книжковий клуб „Клуб сімейного дозвілля”, 2014.

Фромм Э., Бегство от свободы. Человек для себя, перев.Д. Дунинский, Минск: ООО „Поппури”, 1998.

\section{Spysok wykorystanoi literatury [References]}

Buden B., Strefa przejścia. O końcu postkomunizmu [Walkway Zone. About the End of Postcommunism], tłum. M. Sułowski, Warszawa: Wyd-wo Krytyki Politycznej, 2012.

Bäker R., Totalitaryzm. Geneza. Istota. Upadek [Totalitarianism. Genesis. Being. Fall], Toruń: INDEX BOOKS, 1992.

Gołomsztok I., Język artystyczny $w$ warunkach totalitarnych [Artistic Language in the Totalitarian Conditious], thum. A. Mazur, London: Polonia Book Fund L.t.d, 1980.

Hayes C.J., The Novelty of Totalitarianism in the History of Western Civilisation, [in:] „Proceedings of the American Philosophical Society”, 1940, 82(1), p. 91-102.

Kuniński M., Totalitaryzm w ujęciu Hanny Arendt [Totalitarianism in the View of Hanna Arendt], [w:] „Totalitaryzm a zachodnia tradycja”, Kraków, 2006, s. 116-142.

Olszewska-Dyoniziak B., Antropologia totalitaryzmu europejskiego XX wieku [Antropology of the European Totalitarianism of the XX century], Wrocław, 1999.

Arendt Kh., Istoki totalitarizma [The Origins of Totalitarianism], perev. I. V. Borisova, Yu. A. Kimeleva I dr.), Moskva: TSentrKom,, 1996.

Lebon G., Psikhologiya narodov i mass [The Crowd: A Study of the Popular Mind], Moskva: Maket, [v:] Elektronnyj resurs: http://royallib.com/book/lebon_gustav/psihologiya_ narodov_i_mass.html (14.03.2020).

Naimark N., Henotsydy Stalina [Stalin's Genocides], perekl. V. Stark, Kyiv: Vydavnychyi dim „Kyievo-mohylianska akademiia”, 2011.

Ortega-i-Gasset Kh., Vosstanie mass, [The Revolt of the Masses], perev. A. M. Geleskul, [v:] Elektronnyj resurs: http://lib.ru/FILOSOF/ORTEGA/ortega15.txt_with-big-pictures.html (14.03.2020).

Oruehl Dzh., "1984" $i$ ehsse raznykh let ["1984" and Essays of Different Years], perev. V. S. Murav’ev, Moskva: Progress Moskva: Progress, 1989.

Talan S., Rozkolote nebo [The Splitted Sky], Kharkiv: Knyzhkovyi klub „Klub simeinoho dozvillia", 2014.

Fromm Eh., Begstvo ot svobody. Chelovek dlya sebya. [Escape from Freedom. A Man for Himself], perev. D. N. Dudinskij, Minsk: OOO „Poppuri”, 1998. 